\title{
The Ages of Man and the Ages of Woman in Early Medieval England: From Bede to Byrhtferth of Ramsey and the Tractatus de quaternario
}

\author{
Thijs Porck
}

Into how many parts should the human life course be divided? Old English and Anglo-Latin texts show a variety of answers to this question, ranging from three to six distinct stages. Individual authors, such as Bede and Ælfric, alternated between multiple schemes and even in two versions of the same text the number of life stages could differ. An example of the latter phenomenon is found in two versions of an early medieval English confessional prayer. Four stages of life are distinguished in the Old English version that was added to a late eleventh-century manuscript:

Ic eom anddetta for eall pæt unriht be ic æfre gefremede on minum cildhade oððe on minre geogoðe oððe on minre strengðe oððe on minre ylde pe æfter fulwihte agylte 7 on manegum pingum swiðe gode abealh. ${ }^{1}$

I acknowledge all the injustice which I have ever done in my childhood or in my youth or in my strength or in my old age, which I committed after baptism and with many things greatly angered God.

An earlier Latin version of this prayer in the mid-ninth-century Book of Cerne, by contrast, divides the life course into three parts:

1 London, British Library, Cotton Tiberius C.i, fol. 16ov. Henri Logeman, "Anglo-Saxonica Minora, I," Anglia 11 (1889): 101-2, lines 54-57. Unless otherwise noted all translations are my own. In Thijs Porck, Old Age in Early Medieval England: A Cultural History (Woodbridge, 2019), 30-31, 50, I erroneously ascribed this citation to the related prayer in London, British Library, Cotton Vespasian D.xx, which instead reads "Ic eom andetta para pe ic of cildhade oð pas ieldo pe ic æfter fulwihte agylte 7 on manegum ðingum swiðe gode abealh" [I acknowledge those (sins) which I committed from childhood to old age, after baptism, and with many things greatly offended God]. 
confiteor uobis quaecumque feci in puerile aetate uel in iuuentute uel in senectute - et sepe peccaui in multis rebus multum deum inritaui. ${ }^{2}$

I confess to you whatever I committed in puerilis aetas or in iuuentus or in senectus - and I have often sinned and greatly angered God in many things. ${ }^{3}$

Life course schematizations into five or even six 'ages of man' are also found in the wider Old English and Anglo-Latin corpus of homilies, saints' lives and works of a more encyclopedic nature.

In visual artworks from early medieval England, renditions of the human life course occur less frequently and with less variation. Typically, these visualizations depict three male figures, differentiated for age by the presence, length and color of their beards. In this way, the three Magi are depicted on the Franks Casket and a number of early medieval English manuscripts in order to represent all of humanity: the young, the middle-aged and the elderly. ${ }^{4}$ Similarly, the Harley Psalter and Eadwine Psalter follow their Carolingian exemplar, the Utrecht Psalter, in depicting the three Patriarchs (Abraham, Isaac and Jacob) as the three 'ages of man': the first has a slumped neck and a long white or grey beard, the figure in the middle has a black beard, while the third figure is a beardless youth (see Fig. 1.1). ${ }^{5}$

Only one figural depiction of the human life course of a possible preConquest origin departs from this threefold facial hair motif. This depiction, found in Cambridge, Gonville and Caius College, MS 428/428, visualizes four

2 Cambridge, University Library, Ms L1.1.10, fol. 47v, ed. Arthur B. Kuypers, The Prayer Book of Aedeluald the Bishop, Commonly Called the Book of Cerne (Cambridge, 1902), 92-95, lines 15-17. On the relationship between these prayers, see Thijs Porck, "Two Notes on an Old English Confessional Prayer in Vespasian D.xx," Notes and Queries, n.s. 6o (2013): 493-98.

3 In the translations from Latin throughout this contribution, including those by others, Latin age terms infantia, pueritia, adolescentia, iuuentus, senectus and senium, etc., are untranslated, since modern English equivalents (infancy, childhood, adolescence, youth, old age and senility) do not fully capture the often fluctuating early medieval meanings of these words. See, e.g., Adolf Hofmeister, "Puer, iuvenis, senex: Zum Verständnis der mittelalterlichen Altersbezeichnungen," in Papsttum und Kaisertum: Forschungen zur politischen Geschichte und Geisteskultur des Mittelalters: Paul Kehr zum 65. Geburtstag dargebracht, ed. Albert Brackmann (Munich, 1926), 287-316.

4 For a general discussion of the three Magi as the three ages of man, see Elizabeth Sears, The Ages of Man: Medieval Interpretations of the Life Cycle (Princeton, 1986), 91-94; for the early medieval English material, see Porck, Old Age in Early Medieval England, 25-28.

5 For this unique depiction of the three Patriarchs, see Porck, Old Age in Early Medieval England, 28-29. 


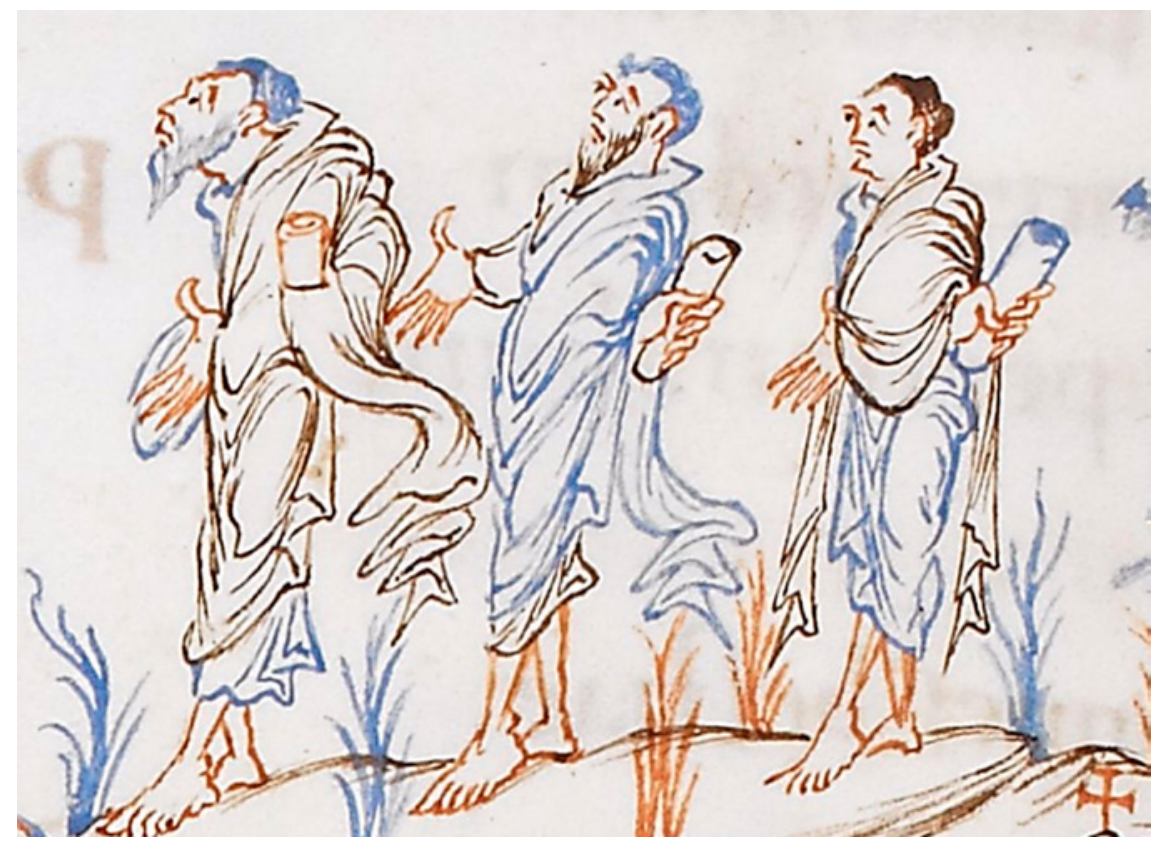

FIGURE 1.1 The three Patriarchs as the three ages of man. London, British Library, Harley 6o3, fol. $52 \mathrm{~V}$

(C) BRITISH LIBRARY BOARD

stages of life, using distinctively female figures (Fig. 1.3 below). ${ }^{6}$ This visualization has received scattered attention in existing scholarship on the medieval life course and its dating and localization is a matter of debate. John Burrow briefly discussed the diagram and its accompanying text, the Tractatus de quaternario, and identified them as the works of an anonymous twelfth-century author of continental origin. ${ }^{7}$ By contrast, Elizabeth Sears ascribed the visualization and the text to an anonymous author writing in early twelfth-century England, ${ }^{8}$ as did Isabelle Cochelin. ${ }^{9}$ Roberta Gilchrist, lastly, opted for a much earlier date and linked the depiction of the four ages of woman to a named individual: "a rare 11th-century example produced by Byrhtferth, a monk of

6 Gonville and Caius College, MS 428/428, fol. $28 \mathrm{v}$. The manuscript is foliated twice in modern pencil due to an error in the foliation in the top right corner (it erroneously counts fol. 27 as fol. 26); in referring to the manuscript, I follow the foliation in the bottom right corner.

7 J. A. Burrow, The Ages of Man: A Study in Medieval Writing and Thought (Oxford, 1986), 20-22.

8 Sears, Ages of Man, 23-25.

9 Isabelle Cochelin, "Introduction: Pre-Thirteenth-Century Definitions of the Life Cycle," in Medieval Life Cycles: Continuity and Change, ed. Isabelle Cochelin and Karen Smyth (Turnhout, 2013), 1-54, at 32-33. 
Ramsey Abbey."10 Before providing a detailed analysis of this depiction of the life course in its manuscript context, this chapter will give a broad overview of the various schematizations of the life course in early medieval England and, in particular, those found in works ascribed to Byrhtferth of Ramsey. In doing so, this chapter not only serves as an introduction to the issue of life course schematization in early medieval England, it also provides the necessary context to determine whether or not the diagram of the four ages of woman can indeed be attributed to one of the most prolific English authors before the Norman Conquest, Byrhtferth of Ramsey.

\section{Life Course Schematizations in Old English and Anglo-Latin Texts}

One of the most insightful contributions to the knowledge of early medieval conceptualizations of the human life course is Cochelin's overview of "more than eighty life-cycle definitions in a variety of sources between the third century and 1200" from all over Western Europe. ${ }^{11}$ Her overview, neatly summarized in a helpful table, provides an insight into the variability of medieval ideas about how the human life course could be stratified. Early medieval authors variously divided life into three to seven stages, using fluctuating and at times contradictory terminology. However, between the sixth century and c.1120, ${ }^{12}$ Cochelin observes a more uniform system of life course stratification. The thirty-four texts from this time period show remarkably less variation than those of earlier and later dates, enabling Cochelin to establish one overarching life course definition:

between the sixth and the early twelfth centuries, the life cycle can contain three, four, five, six or seven ages, because the three main phases, pueritia, iuuentus, and senectus, can each be divided into two and, exceptionally for senectus, even into three ages. A life cycle of three is comprised of the three main phases; one of four means that one of the three phases has been subdivided and so on. Whatever the number of subdivisions, we are still facing one unique, if very flexible, way of conceiving the ages of man..$^{13}$

\footnotetext{
10 Roberta Gilchrist, Medieval Life: Archaeology and the Life Course (Woodbridge, 2012), 253.

11 Cochelin, "Pre-Thirteenth-Century Definitions," 1.

12 The date c.112o is that of the Tractatus de quaternario and its diagram and, as Cochelin, "Pre-Thirteenth-Century Definitions," 32 n. 99, notes, this date is debatable; see below.

13 Cochelin, "Pre-Thirteenth-Century Definitions," 11.
} 
This scheme in sources dated between 500 and c.1120 is further characterized by an almost systematic division of senectus into two or even three stages. Cochelin suggests that a division of old age into two stages may possibly stem from the distinction between an active 'green' old age and a 'grey' old age marked by bodily decline. ${ }^{14}$

Since Cochelin's overview includes only four Anglo-Latin texts (two by Bede, one by Alcuin and one by Byrhtferth), ${ }^{15}$ the question remains whether this flexible life course definition, with its underlying tripartite structure, fully represents early medieval English ideas of the human life course. Cochelin's table can be complemented by an overview of sixteen attestations of the ages of man in Anglo-Latin and Old English texts, here presented as Table 1.1. This table includes only those texts that explicitly describe a schematization of the life course into different stages, from beginning to end, and excludes works by Byrhtferth of Ramsey, which are discussed separately below. ${ }^{16}$ The first column provides information about the text and the three following columns with bold outline represent the three main phases identified by Cochelin: pueritia, iuuentus and senectus. Whenever an author subdivided any of these three main phases, this is indicated by dividing the cell in that particular column; age limits (the supposed end point of a particular stage of life) are added wherever they occur. The texts are listed in a rough chronological order. ${ }^{17}$

\footnotetext{
14 Cochelin, "Pre-Thirteenth-Century Definitions," 14. For this distinction between green and grey old age, see also Pat Thane, "Old Age in English History," in Zur Kulturgeschichte des Alterns: Toward a Cultural History of Aging, ed. C. Conrad and H.-J. von Kondratowitz (Berlin, 1993), 31-32.

15 Cochelin, "Pre-Thirteenth-Century Definitions," 24, 27-28, discusses Bede's De temporibus and De temporum ratione, the Commentaria in s. Joannis euangelium by Alcuin and the work of Byrhtferth of Ramsey.

16 This means that references to individual life stages, such as those in Alcuin's writings discussed in the contribution by Darren Barber in this volume, are not included unless a full range is given from birth to old age. Nor have more allusive references to the human life cycle in Old English poetry been included. For these references, see, e.g., Harriet Soper, "Reading the Exeter Book Riddles as Life-Writing," Review of English Studies 68 (2017): $841-65$.

17 A full analysis of each text is beyond the scope of this contribution and can be found in Porck, Old Age in Early Medieval England, 16-51. The texts that are not discussed in the current chapter are provided with footnote references to the original primary source followed by a short explanatory note.
} 
TABLE 1.1 Divisions of the life course in Anglo-Latin and Old English texts, excluding works by Byrhtferth of Ramsey

$\begin{array}{lll}\text { Main phases } & \text { pueritia } & \text { iuuentus } \\ \text { (Cochelin) } & & \text { senectus }\end{array}$

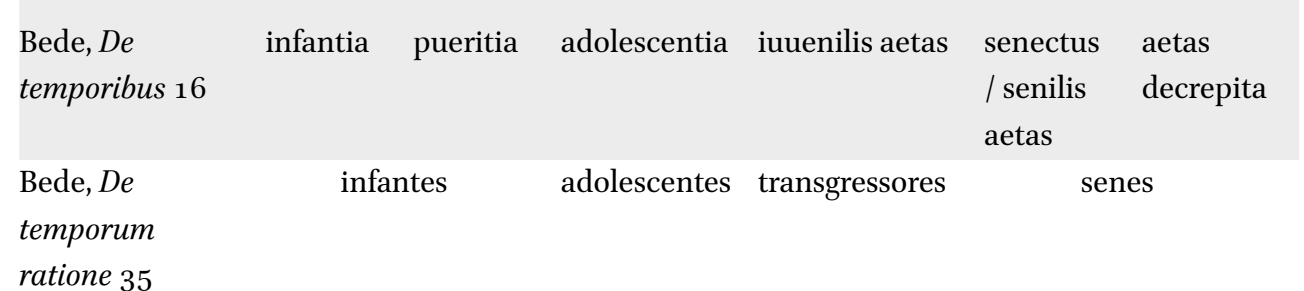

ratione 35

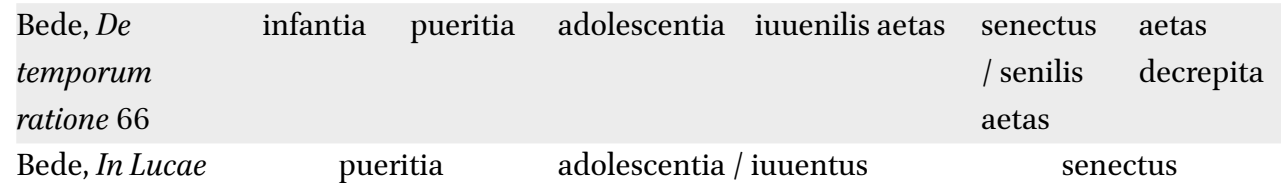

evangelium

expositio

Willibald, Vita infantia pueritia adolescentia iuuentus senectus

Bonifatii $^{\text {a }}$

Alcuin, infantia pueritia adolescentia iuuentus grauitas senectus

Commentarii

in s.Joannis

evangelium

\begin{tabular}{lllllll} 
Ps.-Bede, & infantia & pueritia & adolescentia & iuuentus & senectus & senium / \\
Collectanea & 7 & 14 & 28 & 49 & 77 & decrepitas \\
Confessional & \multicolumn{2}{c}{ puerilis aetas } & \multicolumn{2}{c}{ iuuentus } & & senectus
\end{tabular}

prayer in Book

of Cerne

$\begin{array}{llccccc}\text { Various } & \text { infantia } & \text { pueritia } & \text { adolescentia } & \text { iuuentus } & \text { senectus } & \text { senium / } \\ \text { encyclopedic } & 7 & 14 & 27 / 28 & 48 / 49 & 70 / 77 / 80 & \text { decrepitas } \\ \text { notes } & & & & & & \text { yldo } \\ \text { Blickling Homily } & \text { iugop } & & \text { midfyrhtnes } & & \end{array}$

a Willibald, Vita Bonifatii 9, ed. Reinhold Rau, Bonifatii epistulae. Willibaldi vita Bonifatii (Darmstadt, 1968), 522. In this text, the life of Boniface is divided into five stages.

b Richard Morris, ed., The Blickling Homilies of the Tenth Century, E ETS o.s. 58, 63, 73 (London, 1874-80), 161, 163. This text differentiates between three stages in the lives of the parents of John the Baptist. 
TABLE 1.1 Divisions of the life course in Anglo-Latin and Old English texts (cont.)

\begin{tabular}{llcc}
$\begin{array}{l}\text { Main phases } \\
\text { (Cochelin) }\end{array}$ & pueritia & iuuentus & senectus \\
\hline $\begin{array}{l}\text { Ælfric, homily } \\
\text { for the Common } \\
\text { of a Confessor } \\
\text { (Assmann IV) }\end{array}$ & cildhad & weaxend cnihthad & forwered yld \\
$\begin{array}{l}\text { Ælfric, sermon } \\
\text { for the Octave } \\
\text { of Pentecost }\end{array}$ & cild & geonge menn & ealdan \\
\hline
\end{tabular}

(Pope XI $)^{\mathbf{c}}$

Ælfric, homily

cildhad

cnihthad

geðungen

yld

on the decapita-

wæstm / ful-

tion of John

fremeda wæstm

the Baptist

(Catholic Homilies

I, XXXII) $)^{\mathrm{d}}$

Ælfric, homily

cildhad

cnihthad

geðungen

yld

forwerod

for Septuagesima

wæstm / ful-

ealdnyss

Sunday (Catholic

fremeda wæstm

Homilies II, v)

Wulfstan, "De

cild

medeme ylde mann

eald geðungen mann

temporibus

Antichristi"e

Confessional

cildhad

geogoð

strengð

yld

prayer in Cotton

Tiberius C.i

c Ælfric, Homilies of Elfric: A Supplementary Collection, ed. John C. Pope, EETS o.s. 259-6o (Oxford, 196768), hom. 11, lines 112-17. This text relates the three types of deaths (bitter, immature and natural) to three ages of man.

d Ælfric, Catholic Homilies: The First Series, ed. Peter Clemoes, EETs s.s. 17 (Oxford, 1997), hom. 32, ll. 208 -11. Four stages of life mentioned in the context of the changing nature of the human body.

e Wulfstan, Eschatological Homilies, ed. and trans. Joyce Tally Lionarons (2000), http://webpages .ursinus.edu/jlionarons/wulfstan/Wulfstan.html. In this text, the three stages refer to the physical forms that the shapeshifter Simon Magus takes on in his confrontation with Saints Peter and Paul. 
On the whole, these early medieval English texts conform to what Cochelin had observed for the bulk of texts made between the sixth century and c.1120: the life course was typically conceptualized as consisting of three main phases (pueritia, iuuentus, and senectus), which could each be subdivided. ${ }^{18}$ While many life course definitions feature senectus divided into two stages, a division into three stages as found in some of Cochelin's examples, is not present in the early medieval English corpus. Cochelin's further suggestion that a subdivided old age in these schemes stems from a distinction between active advanced age and old age proper cannot be verified for the early medieval English material, since in some of these texts even the first stage of senectus is defined by bodily weakness. In fact, as I have demonstrated elsewhere, old age in early medieval England was more broadly conceived of as a single long phase, starting at the age of forty-eight, forty-nine, or fifty and characterized specifically by physical decline. ${ }^{19}$

Cochelin rightly notes that early medieval life course definitions cannot be presumed to be representative of society at large. They typically stem from a learned, ecclesiastical milieu and were produced by male authors. ${ }^{20}$ This holds true for the texts included in Table 1.1 as well. Those early medieval English authors who commented on the human life course typically followed earlier models by Church Fathers, such as Gregory the Great, Augustine of Hippo and Isidore of Seville. Their influence on early medieval English life course schematization is traced in the following section.

\section{2 \\ The Learned Context: Biblical Exegesis, Patristic Tradition and Natural Philosophy}

Medieval authors who commented on a threefold division of the life course mostly did so in the context of biblical exegesis. Biblical triads, such as the three Magi and the three Patriarchs, could be interpreted as representing different stages of human life and, as a group, they could represent all of mankind. ${ }^{21} \mathrm{~A}$ good example of this approach is Bede's interpretation of Christ's Parable of the Three Vigils (Luke 12.36-38). In this parable, Christ compares his disciples to servants awaiting their lord's return from a wedding during three vigils - in

18 Cochelin, "Pre-Thirteenth-Century Definitions," 11.

19 Porck, Old Age in Early Medieval England, 49.

20 Cochelin, "Pre-Thirteenth-Century Definitions," 2.

21 Porck, Old Age in Early Medieval England, 25-29. 
Bede's commentary, each of these vigils represents a stage of life during which a person might turn to God:

Prima quippe uigilia primaeuum tempus est, id est pueritia; secunda adulescentia uel iuuentus quae auctoritate sacri eloquii unum sunt dicentis: laetare iuuenis in adulescentia tua; tertia autem senectus accipitur. Qui ergo uigilare in prima uigilia noluit custodiat uel secundam ut qui conuerti a prauitatibus suis in pueritia neglexit ad uias uitae saltim in tempore iuuentutis euigilet. Et qui uigilare in secunda uigilia noluit tertiae uigiliae remedia non amittat ut qui et in iuuentute ad uias uitae non euigilat saltim in senectute resipiscat. ${ }^{22}$

Indeed, the first vigil is the youthful time, which is pueritia. The second, adolescentia or iuuentus, which according to the authority of the sacred word are the same, saying: 'Rejoice, $\mathrm{O}$ iuuenis, in your adolescentia' (Eccles. 11.9). ${ }^{23}$ The third, moreover, is accepted to be senectus. Therefore, whoever did not want to be awake during the first vigil, should observe the second, so that whoever has neglected to turn away from vices in pueritia, is at least watchful of the ways of life in the time of iuuentus. And whoever did not want to be alert during the second vigil, may they not let go of the remedies of the third watch, so that whoever is also not watchful of the ways of life in iuuentus, at least recovers their senses in senectus.

Bede's commentary, which explains that it is never too late to turn to a Christian way of life, was copied verbatim from a homily by Gregory the Great (c.540-604) ${ }^{24}$ In his Old English homily for the Common of a Confessor, Ælfric of Eynsham interpreted the three Vigils in a similar manner, following Bede or

22 Bede, In Lucae evangelium expositio, ed. D. Hurst, CCSL 120 (Turnhout, 1960), 257, lines 1039-58.

23 The notion that adolescentia and iuuentus are interchangeable terms, backed up by the quotation from Ecclesiastes 11.9, is indicative of one of the recurring problems in medieval writings about the human life course: the relative fluidity of the terminology. See, e.g., Hofmeister, "Puer, iuvenis, senex," 287-316. In most other early medieval divisions of the life course in Table 1.1, adolescentia denotes the stage of life preceding iuuentus. In his exposition of the four ages of man in his De temporum ratione, Bede used the term adolescentes to denote the second stage of life, but avoided terminology related to iuuentus altogether, opting for transgressores instead. Whenever Bede divided the life course into six stages of life, he did distinguish between adolescentia and iuuenilis aetas as the two stages preceding senectus; see below.

24 Gregory, Homiliae in evangelia, ed. R. Étaix, ccsL 141 (Turnhout, 1999), hom. 13, lines $74-82$. 
Gregory as well as Haymo of Auxerre, and he uses the terms "cildhade" [childhood], "weaxendum cnihthade" [growing youth/adolescence] and "forweredre ylde" [worn-out old age] to render the three stages of life. ${ }^{25}$

In another homily, Ælfric interpreted another one of Christ's parables in terms of the ages of man. In this case, he favored a fivefold division of life to interpret Christ's Parable of the Vineyard (Matt. 20.1-16). According to Ælfric, people could become Christians during five different periods in their lives and still reap the same reward, analogous to how, in the parable, workers were called to a vineyard at five different hours:

Eornostlice ponne sume beoð gelædde on cildhade to godum ðeawum and rihtum life. sume on cnihthade. sume on geðungenum wæstme. sume on ylde. sume on forwerodre ealdnysse. ponne bið hit swylce hi beon on mislicum tidum to ðam wingearde gelaðode. ${ }^{26}$

Truly some are led in childhood to good deeds and a righteous life, some in youth, some in mature growth, some in old age, some in worn-out old age; then it is as though they had at diverse times been called to the vineyard.

Ælfric's Old English text is a near word-for-word translation of the corresponding passage in a homily by Gregory the Great, showing once more how many of these early medieval English definitions of the life course find their origins in patristic writings. ${ }^{27}$

Patristic tradition also underlies a number of early medieval English life course definitions that refer to six individual stages of life. Bede and Alcuin, for instance, both drew on Augustine of Hippo when they related the six ages of man to the sex aetates mundi [six ages of the world]. ${ }^{28}$ In various works, Augustine had propagated the idea that the world passes through six ages which correspond to the human life course: infantia (from Adam to Noah), pueritia

25 Bruno Assmann, ed., Angelsächsische Homilien und Heiligenleben (Kassel, 1889), hom. 4, lines 67-83. For a discussion of Ælfric's sources, see Porck, Old Age in Early Medieval England, 22.

26 Ælfric, Catholic Homilies: The Second Series, ed. Malcolm Godden, EETs s.s. 5 (London, 1979), hom. 5, lines 101-6.

27 Milton McC. Gatch, Preaching and Theology in Anglo-Saxon England: Alfric and Wulfstan (Toronto, 1977), 93-94; Malcolm Godden, Elfric's Catholic Homilies: Introduction, Commentary and Glossary, EETs s.s. 18 (Oxford, 200o), 383-84.

28 Alcuin's use of this motif in his Commentarii in s. Joannis evangelium is discussed in Burrow, Ages of Man, 84-85; Porck, Old Age in Early Medieval England, 39-41. 
(from Noah to Abraham), adolescentia (from Abraham to David), iuuentus (from David until the Babylonian captivity), senioris (from the Babylonian exile to the coming of Jesus Christ) and, finally, senectus which would last until the end of time. ${ }^{29}$ Bede included a version of this Augustinian division into six ages in both his De temporibus and his De temporum ratione. In both texts, he distinguished between infantia, pueritia, adolescentia, iuuenilis aetas, senilis aetas / senectus and aetas decrepita ${ }^{30}$; the most elaborate treatment of this sixfold scheme is the one in his De temporum ratione:

Quae uniuersali est deleta diluuio, sicut primam cuiusque hominis obliuio demergere consueuit aetatem; quotus enim quisque est, qui suam recordetur infantiam? [...] Haec quasi pueritia fuit generis populi Dei et ideo in lingua inuenta est, id est Hebrea, a pueritia namque homo incipit nosse loqui post infantiam, quae hinc appellata est, quod fari non potest. [...] Haec quaedam uelut adolescentia fuit populi Dei, a qua aetate quia incipit homo posse generare [...]. A qua uelut iuuenali aetate in populo Dei regum tempora coeperunt, haec namque in hominibus aetas apta gubernando solet existere regno. Quinta quasi senilis aetas [...] [i]n qua, ut graui senectute fessa, malis crebrioribus plebs Hebrea quassatur. Sexta $[\ldots]$ aetas $[\ldots]$ sed ut aetas decrepita ipsa totius saeculi morte consumenda. ${ }^{31}$

This (First Age) was wiped out in the universal Flood, just as the first age of every person is usually submerged in oblivion, for how many people can remember their infantia? ... This (Second Age) was, so to speak, the pueritia of God's people, and therefore it is discovered in a language, that is, in Hebrew, because from pueritia on, when infantia is over - which is so called because an infant cannot speak - a person begins to learn to speak.... This (Third Age) was like the adolescentia of the people of God, because from this age on, a person can reproduce.... From this (Fourth) Age - iuuenilis aetas, so to speak - the era of the kings began among the people of God, for this age in man is normally apt for governing a kingdom. The Fifth Age - senilis aetas, if you will - ... in this Age the Hebrew people were weakened by many evils, as if wearied by heavy senectus....

29 Sears, Ages of Man, 54-61.

30 Bede, De temporibus 16, ed. C. W. Jones, Opera didascalica, Ccsl 123 C (Turnhout, 1980), 6oo-6o1; Bede, De temporum ratione 66, ed. C. W. Jones, Opera didascalica, CcsL 123 B (Turnhout, 1977), 463-64. Also discussed in Cochelin, "Pre-Thirteenth-Century Definitions," 24.

Bede, De temporum ratione 66, ed. Jones, 463-64. 
The Sixth Age ... like aetas decrepita, this (Age) will come to an end in the death of the whole world. ${ }^{32}$

While this life course schematization features a subdivision of old age, both parts, according to Bede, are marked by decline; as such, this life course definition does not feature a transition from a young, active old age to a weakened old age.

In addition to the works of Augustine, Isidore of Seville's treatments of the sixfold division of life in his Differentiae and Etymologiae were highly influential in the early Middle Ages. ${ }^{33}$ For instance, Isidore's divisions are found in two ninth-century works once ascribed to Bede and Alcuin, respectively. ${ }^{34}$ Isidore's work on the life course was also regularly copied in the form of encyclopedic notes that are found in various manuscripts from early medieval England. ${ }^{35}$ One of these notes demonstrates some of the variability in this sixfold division in terms of the length in years ascribed to each stage:

Prima ætas infantia .vii. annis. Secunda. pueritia . xiiii. tertia adulescentia .xxvii. annis. Quarta iuuentus . xlviii. uel .viiii. annis. Quinta senectus usque ad .lxx. uel .lxxx. annos. ab anno .lxxesimo, uel xxxesimo. Senium id est decrepitus et nimium senex dicitur. Infantia habet unam ebdomadam annorum. id est vii. annos pueritia alios .vii. adulescentia duas

32 Bede, The Reckoning of Time, trans. Faith Wallis (Liverpool, 2004), 157-58.

33 Isidore, Differentiae 2.19, PL 83, cols. 81b-c; Isidore, Etymologiae 11.2.2-8, trans. Stephen A. Barney, W. J. Lewis, J. A. Beach, and Oliver Berghof (Cambridge, 2006), 241. In both texts, Isidore gives six ages, but he gives different age limits and names for the last three: in the Differentiae, infantia (7), pueritia (14), adolescentia (28), iuuentus (49), senectus (77) and senium (no age limit); in the Etymologiae, infantia (7), pueritia (14), adolescentia (28), iuuentus (50), grauitas / senioris aetas (70), senectus / senium (no age limit).

34 The ninth-century Collectanea Pseudo-Bedae gives a sixfold division of life, with the age limits as found in Isidore's Differentiae; Collectanea Pseudo-Bedae, ed. and trans. Martha Bayless and Michael Lapidge (Dublin, 1998), no. 378. Michael Lapidge, "The Origin of the Collectanea," in Collectanea, ed. and trans. Bayless and Lapidge, 12, notes that the material in this text derives either from Ireland, England or the Continent: "the majority of its localizable contents originated either in Ireland or England, or in an Irish foundation on the continent." Isidore's discussion in the Etymologiae is the source for the treatment of the six ages in the Disputatio puerorum, once ascribed to Alcuin. The latest editors of this text now refute this attribution, hence it has not been included in Table 1.1 above; The Disputatio puerorum: A Ninth-Century Monastic Instructional Text. Edited from Vienna, Österreichische Nationalbibliothek, 458, ed. Andrew Rabin and Liam Felsen, Toronto Medieval Latin Texts 34 (Toronto, 2017).

35 On these notes, see Kees Dekker, "Anglo-Saxon Encyclopaedic Notes: Tradition and Function," in Foundations of Learning: The Transfer of Encyclopaedic Knowledge in the Early Middle Ages, ed. Rolf H. Bremmer Jr and Kees Dekker (Paris, 2007), 279-315; Porck, Old Age in Early Medieval England, 40-43. 
ebdomadas. id est anni .xxviii. Iuuentus iii. ebdomadas. id sunt anni .xlviiii. Senectus .iiii. ebdomadas. id sunt. anni . lxxvii. ebdomadas .xi. Senium nullo certo annorum numero finitur.

The first age, infantia, (lasts to) seven years. The second, pueritia, (to) fourteen years. The third, adolescentia, (to) twenty-seven years. The fourth, iuuentus, (to) forty-eight or -nine years. The fifth, senectus, to seventy or eighty years. From the seventieth or eightieth year, senium, which is decrepitas, and is said to be old age beyond measure. Infantia has one hebdomad of years - this is seven years - pueritia another seven. Adolescentia has two hebdomads - this is twenty-eight years. Iuuentus has three hebdomads - these are forty-nine years. Senectus has four hebdomads - these are seventy-seven years (or) eleven hebdomads. Senium is not ended by any certain number of years. ${ }^{36}$

In listing a range of different age limits for each stage, this note conflates various versions of the six ages of man, combining as it does the cut-off points for each stage in Isidore's Differentiae $(7,14,28,49,77)$ and Etymologiae $(7,14,28$, $\left.5^{\circ}, 70\right)$, as well as adding three more alternative age limits ( 27 for adolescentia, 48 for iuuentus and 80 for senectus). ${ }^{37}$ As such, this note is an amalgamation of slightly differing divisions of the six ages of man that circulated in early medieval England.

Another major intellectual tradition that influenced the way authors looked at the human life course in the Middle Ages was natural philosophy. This tradition primarily influenced those authors who conceptualized a life course of four and later seven stages. ${ }^{38} \mathrm{~A}$ fourfold division of human life, analogous to four seasons in the course of a year, is generally attributed to the Greek philosopher Pythagoras (c.570-c.495 BC).$^{39}$ Later, other sets of four, such as the

36 Edition and translation from Dekker, "Anglo-Saxon Encyclopaedic Notes," 283, 314. This note occurs in at least five manuscripts from early medieval England, dated between the ninth and eleventh centuries. The note is included in Cochelin's overview as "Manuscript from Paris (Tenth Century)," Cochelin, "Pre-Thirteenth-Century Definitions," 27.

The age limit 27 for adolescentia is also found in the anonymous ninth-century Disputatio puerorum 3.3, ed. Rabin and Felsen, 43, line 691; the age limit 48 for iuuentus is also used in Byrhtferth's famous diagram; see below. The notion that senectus ends at the age of 70 or 8 o may be based on Psalm 89.10 ("The days of our years in them are threescore and ten years. But if in the strong they be fourscore years"); Bible references and translations are from the Douay-Rheims translation of the Latin Vulgate.

38 Burrow, Ages of Man, $12-54$.

39 The Four Seasons of Human Life: Four Anonymous Engravings from the Trent Collection, ed. H. F. J. Horstmanshoff et al. (Rotterdam, 2002), 40-41. 
elements and the humors, were incorporated into this tetradic scheme. ${ }^{40}$ In early medieval England, this interrelation between the physical and physiological fours is first found in Bede's De temporum ratione. Here, Bede describes how the four ages of man correspond to four other sets of 'fours': the seasons, the qualities, the elements and the humors. First, the four seasons are linked to four qualities: spring is moist and hot, summer is hot and dry, autumn is dry and cold and winter is cold and moist. These same four qualities are found in the four elements, air, fire, earth and water. Analogous to the four seasons and four elements, people can be divided into four age categories: infantes, adolescentes, transgressores and senes. ${ }^{41}$ Bede then connects the four ages to the four bodily humors and outlines the typical behavioral characteristics that these dominating humors produce within mankind:

Et quidem sanguis in infantibus maxime uiget, in adolescentibus cholera rubea, melancholia in transgressoribus, id est fel cum faece nigri sanguinis admixtum, phlegmata dominantur in senibus. Item sanguis eos in quibus maxime pollet facit hilares, laetos, misericordes, multum ridentes et loquentes; cholera uero rubea faciunt macilentos, multum tamen comedentes, ueloces, audaces, iracundos, agiles; nigra bilis stabilis, graues, compositos moribus, dolosos que facit; phlegmata tardos, somnolentos, obliuiosos generant. ${ }^{42}$

Indeed, blood is at its most active in children, red bile in young people, melancholia (that is, gall mingled with the dregs of black blood) in the middle-aged, and phlegmatic humors dominate in the elderly. Moreover, blood makes those in whom its potency is greatest cheerful, joyous, tender-hearted, much given to laughter and speech; red bile makes people lean, even though they eat a lot, swift, bold, irritable and agile; black bile makes them stolid, solemn, set in their ways and gloomy; phlegmatic humors produce people who are slow, sleepy and forgetful. ${ }^{43}$

Bede's rendition for the physical and physiological fours is set out schematically in Table 1.2. ${ }^{44}$

\footnotetext{
$40 \quad$ Sears, Ages of Man, 9-16.

41 Bede, De temporum ratione 35, ed. Jones, 391-95.

42 Bede, De temporum ratione 35, ed. Jones, 392-93.

43 Bede, Reckoning, trans. Wallis, 101.

44 For a discussion of Bede's sources, see Porck, Old Age in Early Medieval England, 33.
} 
TABLE 1.2 Bede's scheme of physical and physiological fours

\begin{tabular}{lllll}
\hline Qualities & moist and hot & hot and dry & dry and cold & cold and moist \\
Season & spring & summer & autumn & winter \\
Elements & air & fire & earth & water \\
Ages of man & infantes & adolescentes & transgressores $^{\text {a }}$ & senes \\
Humors & blood & red bile & black bile & phlegm \\
\hline
\end{tabular}

a Bede's use of the term transgressores is unusual and it is not entirely clear which stage of life he might be referring to here. Cochelin, "Pre-Thirteenth-Century Definitions," 24, interprets the term as denoting the stage of life starting at the age of forty-nine, usually denoted as grauitas or senectus in other early medieval life course definitions, especially since Bede ascribes to the transgressores "grauis" [solemn] behaviour. To this, we can add that Bede in his exposition of the Parable of the Three Vigils had noted how adolescentia and iuuentus were equivalent terms. However, in most other medieval definitions of the life course, adolescentia ends at the age of twenty-eight and rarely directly precedes the onset of old age and it does not do so in Bede's rendition of the six ages of man, where adolescentia is followed by iuuenilis aetas. Moreover, Byrhtferth of Ramsey, who based his discussion of the four ages on Bede, interprets Bede's transgressores as representing iuuentus (see below). As such, Bede's fourfold division here seems to represent a single, undivided first stage of pueritia (the infantes), a subdivided stage of iuuentus (represented by the adolescentes and transgressores) and a single, undivided last stage of senectus (the senes).

To sum up thus far, when commenting on the human life course, early medieval English authors typically followed earlier traditions and, depending on the genre in which they were writing, they could unproblematically alternate, as in the case of Bede, between three, four or six ages of man.

Byrhtferth of Ramsey was one of the most prolific English authors in Latin and Old English with an oeuvre that ranges from computus to hagiography. His most famous work is his Manual or Enchiridion (1010-1012), which was intended as a handbook for the use of a now-lost Computus that he had produced earlier. This Computus, a collection of diagrams, formulae and texts on the subjects of time and numerology, has been reconstructed on the basis of three twelfth-century manuscripts, which also contain diagrams that are explicitly attributed to Byrhtferth. ${ }^{45} \mathrm{He}$ also wrote two saints' lives, devoted

45 Byrhtferth, Enchiridion, ed. and trans. Peter S. Baker and Michael Lapidge, EETS s.s. 15 (London, 1995). 
to St. Oswald and St. Ecgwine. ${ }^{46}$ In addition, Byrhtferth may also have been a glossator: a set of explanatory glosses to Bede's De natura rerum and De temporum ratione have been ascribed to Byrhtferth, ${ }^{47}$ and some glosses that survive in manuscripts of the Enchiridion and the Vita s. Ecgwini may also have been made by him. ${ }^{48}$ Throughout his works, Byrhtferth found ample occasion to refer to the various stages of the human life course, as the overview in Table 1.3 demonstrates. ${ }^{49}$

TABLE 1.3 Life course divisions found in works by Byrhtferth

\begin{tabular}{lll}
\hline $\begin{array}{l}\text { Main phases } \\
\text { (Cochelin) }\end{array}$ & pueritia iuuentus & senectus \\
\hline
\end{tabular}

\begin{tabular}{|c|c|c|c|c|}
\hline $\begin{array}{l}\text { Enchiridion } 1.1, \\
\text { lines } 102-13\end{array}$ & pueritia & adolescentia & iuuentus & senectus \\
\hline $\begin{array}{l}\text { Enchiridion 1.1, } \\
\text { lines } 120-33\end{array}$ & $\begin{array}{l}\text { cildhad / } \\
\text { cildiugoð / } \\
\text { cildyld }\end{array}$ & cnihtiugoð & $\begin{array}{l}\text { gepungen } \\
\text { yld }\end{array}$ & $\begin{array}{l}\text { swyðe eald } \\
\text { yld / yld }\end{array}$ \\
\hline $\begin{array}{l}\text { Enchiridion } 4.1 \text {, } \\
\text { lines } 74-84\end{array}$ & pueritia & adholescentia & iuuentus & senectus \\
\hline $\begin{array}{l}\text { Glosses to } E \text { 4.1, } \\
\text { lines } 74-84\end{array}$ & cildhad & cnihthad & $\begin{array}{l}\text { gepungen } \\
\text { yld }\end{array}$ & fulre yld \\
\hline Enchiridion diagram 3 & pueritia & adolescentia & iuuentus & senectus \\
\hline Enchiridion diagram 13 & pueritia & adolescentia & iuuentus & senectus \\
\hline Enchiridion diagram 15 & pueritia & adolescentia & iuuentus & senectus \\
\hline
\end{tabular}

46 For these texts and a complete overview of Byrhtferth's writings, see Byrhtferth, The Lives of St Oswald and St Ecgwine, ed. and trans. Michael Lapidge (Oxford, 2009), xxx-xliv.

47 See Michael Lapidge, "Byrhtferth of Ramsey and the Glossae Bridferti in Bedam," Journal of Medieval Latin 17 (2008): 384-400. The identification of Byrhtferth as the author of these glosses is controversial, cf. John J. Contreni, "Old Orthodoxies Die Hard: Herwagen's Bridferti Ramesiensis Glossae," Peritia 22-23 (2011-2012, 2013): 15-52. Regardless of the identity of the author, these glosses will not be discussed here, since the notes to the chapters in De temporum ratione that are relevant to this contribution (chapters 35 and 66) do not touch on the ages of man. The glosses were published from a now-lost manuscript in Johannes Herwagen's 1563 edition of Bede's works; they are reprinted in PL 9o; for the glosses on chapters 35 and 66 , see cols. $457 \mathrm{~d}, 5^{20-21}$.

48 Byrhtferth, Lives, ed. and trans. Lapidge, 305 .

49 The references to the Enchiridion and its diagrams are to Byrhtferth, Enchiridion, ed. and trans. Baker and Lapidge. References to the Vita s. Ecgwini are to Byrhtferth, Lives, ed. and trans. Lapidge. 
TABLE 1.3 Life course divisions found in works by Byrhtferth (cont.)

\begin{tabular}{lllll}
\hline $\begin{array}{l}\text { Main phases } \\
\text { (Cochelin) }\end{array}$ & pueritia & \multicolumn{2}{c}{ iuuentus } & senectus \\
\hline $\begin{array}{llll}\text { De concordia mensium } \\
\text { atque elementorum }\end{array}$ & $\begin{array}{l}\text { pueritia / } \\
\text { infantia }\end{array}$ & adolescentia & iuuentus & $\begin{array}{l}\text { senectus } \\
70 / 80\end{array}$ \\
& 14 & & 48 & \\
Vita s. Ecgwini preface & pueritia & adolescentia & iuuentus & senectus \\
Vita s. Ecgwini 1.6 & pueritia & adolescentia & iuuentus & senectus \\
Glosses to VSE 1.6 & pueritia & adolescentia & iuuentus & senectus \\
& $7 / 8$ & 14 & 50 & \\
\hline
\end{tabular}

This overview shows a particular consistency in Byrhtferth's use of Latin terminology and his preference for a fourfold division of the human life course. Less consistent was his use of vernacular age terminology. In the main text of his Enchiridion, Byrhtferth used no fewer than three different terms to render pueritia (cildhad, cildiugoð and cildyld) and two terms for senectus (swyðe eald yld and $y / d$ ), while giving only one vernacular translation for adolescentia (cnihtiugoð) and iuuentus (gepungen yld). If the Old English glosses to the Enchiridion are indeed Byrhtferth's own, they add another two vernacular alternatives: cnihthad for adolescentia and fulre yld for senectus. Thus, Byrhtferth's work demonstrates the difficulty of finding Old English alternatives for Latin age terminology. ${ }^{50}$

Byrhtferth seems to have based his preference for a fourfold division of the human life course on Bede's rendition of the physical and physiological fours in De temporum ratione, a text with which he was certainly familiar. ${ }^{51}$ In Book One of his Enchiridion, Byrhtferth outlines how the four seasons, elements and ages are all connected through their shared qualities. He provided his text in Latin, intended for reformed monks, and in Old English, for secular clerics. The Latin text runs as follows: 52

\footnotetext{
$5^{\circ} \quad$ See also Daria Izdebska's contribution to this volume.

$5^{1}$ Parts of this text were probably part of his Computus and one now-lost manuscript contained a set of explanatory glosses to Bede's De temporum ratione that may be Byrhtferth's; see note 47 above.

$5^{2}$ For a discussion of Byrhtferth's Old English rendition of this passage, see Philippa Semper, "Byð se ealda man ceald and snoflig: Stereotypes and Subversions of the Last Stages of the Life Cycle in Old English Texts and Anglo-Saxon Contexts," in Cochelin and Smyth, Medieval Life Cycles, 290-91.
} 
Ver et pueritia consentiunt; adolescentia et estas assimilantur; autumnus et iuuentus consociantur; hiems et senectus deficiuntur. Ver humidum et calidum, aer humidus et calidus; pueritia humida et calida. Sanguis, qui in pueris pollet, humidus et calidus est. Aestas calida et sicca; ignis calidus et siccus; adolescentia calida et sicca. Colera rubea crescunt in $<$ adolescentibus $>$; calida et sicca <sunt $>$. Autumnus siccus et frigidus; terra sicca et frigida; iuuentus sicca et frigida. Colera nigra in autumno crescunt; sicca et frigida sunt. Hiemps frigida et humida; aqua frigida et humida; flegmata dominantur in senibus. Colera nigra (id est melancolia) in transgressoribus uiget (id est qui $<$ in $>$ iuuentute sunt).

Spring and pueritia go together; adolescentia and summer are similar; autumn and iuuentus are associated; winter and senectus decline. Spring is moist and hot, air is moist and hot, pueritia is moist and hot. The blood which prevails in children, is moist and hot. Summer is hot and dry; fire is hot and dry; adolescentia is hot and dry. Red choler flourishes in adolescentia; it is hot and dry. Autumn is dry and cold; earth is dry and cold; iuuentus is dry and cold. Black choler flourishes in autumn; it is dry and cold. Winter is cold and moist; water is cold and moist; phlegm prevails among the aged. Black choler (that is, melancholy) flourishes in those in a state of transition (that is in their iuuentus). ${ }^{53}$

As Michael Lapidge has demonstrated, Byrhtferth's text here relies heavily on a gloss by Remigius (d. 908) on Boethius's De consolatione philosophiae. Lapidge further notes that some discrepancies in wording between Remigius and Byrhtferth suggest that he is also drawing on Bede's discussion of the four ages in De temporum ratione..$^{54}$ Specifically, Byrhtferth clarifies what Bede had meant with the unusual term "transgressores" to denote the third age category. While Cochelin has suggested that for Bede "transgressores seems not to refer to iuuentus, but more probably to the stage starting at forty-nine" [i.e. senectus $],{ }^{55}$ Byrhtferth defines the transgressores as those who are in iuuentus, a stage of life that, according to him, lasts until the age of 48 or $50 .{ }^{56}$

53 Byrhtferth, Enchiridion 1.1, lines 103-13, ed. and trans. Baker and Lapidge, 10-13.

54 Michael Lapidge, "Byrhtferth at Work," in Words and Works: Studies in Medieval English Language and Literature in Honour of Fred C. Robinson, ed. Peter S. Baker and Nicholas Howe (Toronto, 1998), 31.

55 Cochelin, "Pre-Thirteenth-Century Definitions," 24; see also note a to Table 1.2 above.

56 These age limits are not mentioned in the Enchiridion but elsewhere; see below. 
Byrhtferth used the same Latin terminology for the four ages (pueritia; adolescentia; iuuentus; senectus) elsewhere in the Enchiridion, as well as in a number of diagrams that were used to illustrate parts of the work. These passages and diagrams repeat the links between the ages, seasons and elements, and further develop the idea of tetradic correspondences. One diagram links the four ages to the four wind directions, while another draws a connection with four spiritual virtues: pueritia is equated with the West and justice, adolescentia with the North and prudence, iuuentus with the East and temperance and senectus with the South and fortitude. ${ }^{57}$

One further diagram survives in the two twelfth-century manuscripts that likely contain versions of the Computus compiled by Byrhtferth, for which the Enchiridion was intended as a handbook. This diagram is known as 'Byrhtferth of Ramsey's diagram of the physical and physiological fours', although Byrhtferth himself called it De concordia mensium atque elementorum [On the concord of the months and elements]. ${ }^{58}$ The diagram (Fig. 1.2) visualizes how various aspects of the universe (the elements, seasons, ages of man, wind directions and months) all exist in perfect symmetry. In line with the discussion in the Enchiridion, the four ages correspond to the four seasons, elements and wind directions in sharing the same combination of qualities. Breaking with his consistent use of Latin age terminology throughout the Enchiridion, Byrhtferth here supplies infantia as an equivalent term for pueritia. In addition, this diagram adds age limits for each stage of life: pueritia or infantia ends after fourteen years, adolescentia after twenty-eight years, iuuentus ends after forty-eight years and senectus ends after seventy or eighty years. Byrhtferth's age limits for the first two ages correspond with those propagated by Isidore of Seville, ${ }^{59}$ while the age limit for senectus (ending at seventy or eighty) is likely inspired by Psalm 89.10 ("The days of our years in them are threescore and ten years. But if in the strong they be fourscore years"). The information provided by Byrhtferth throughout his Enchiridion and the diagrams ascribed to him is summarized in Table 1.4.

57 These diagrams are reconstructed as figures 13 and 15 in Byrhtferth, Enchiridion, ed. Baker and Lapidge, $76-77,86-87$. For a discussion of these diagrams and their didactic function, see Philippa Semper, "Doctrine and Diagrams: Maintaining the Order of the World in Byrhtferth's Enchiridion," in The Christian Tradition in Anglo-Saxon England:Approaches to Current Scholarship and Teaching, ed. Paul Cavill (Cambridge, 2004), 121-37.

$5^{8}$ London, British Library, Harley 3667 , fol. 8r; Oxford, St. John's College, 17, fol. $7 \mathrm{v}$. The diagram is reproduced as Appendix A. 3 in Byrhtferth, Enchiridion, ed. Baker and Lapidge, $373^{-74}$.

See note 33 above. 


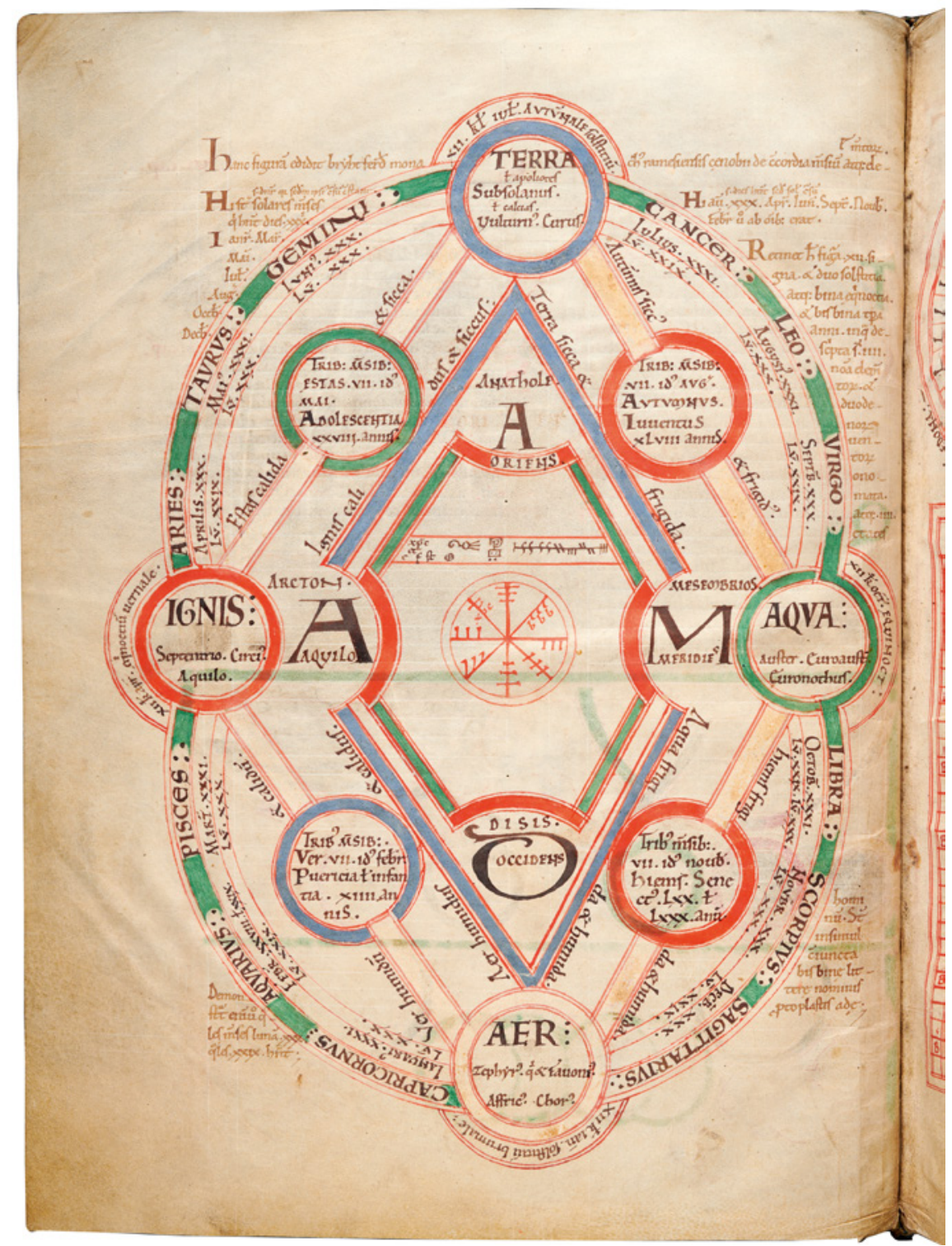

FIGURE 1.2 Byrhtferth's diagram in Oxford, St John's College, 17, fol. $7 \mathrm{~V}$ BY PERMISSION OF THE PRESIDENT AND FELLOWS OF ST JOHN'S COLLEGE OXFORD 
TABLE 1.4 Byrhtferth's system of tetradic correspondences relating to the ages of man

\begin{tabular}{lllll}
\hline Ages & $\begin{array}{l}\text { pueritia / } \\
\text { infantia }\end{array}$ & adolescentia & iuuentus & senectus \\
\hline Qualities & moist and hot & hot and dry & dry and cold & cold and moist \\
Humors & blood & red bile & black bile & phlegm \\
Seasons & spring & summer & autumn & winter \\
Elements & air & fire & earth & water \\
Wind directions & West & North & East & South \\
Virtues & justice & prudence & temperance & fortitude \\
Age limits & 14 & 28 & 48 & $70 / 80$ \\
\hline
\end{tabular}

Outside of the Enchiridion and its associated diagrams, Byrhtferth used the four ages of man explicitly to structure his saint's life of Ecgwine, bishop of Worcester (?693-717) and founder of Evesham Abbey. This Vita s. Ecgwini (1016-1020) is divided into four books, in accordance with the fourfold division of the life course. In doing so, Byrhtferth hopes to demonstrate "qualiter [...] sanctus Dei presul Ecguuinus enituerit in pueritia, fulserit in adolescentia, floruerit in iuuentute et in senectute ceu emeritus miles permanserit" [how St Ecgwine, the holy bishop of God, shone during pueritia, glittered in adolescentia, blossomed in iuuentus and in senectus remained like a veteran soldier]. ${ }^{60}$ A set of glosses in the only extant manuscript of the Vita s. Ecgwini have been ascribed to Byrhtferth by Lapidge on account of the correspondence they show with Byrhtferth's other works. The glosses to the Latin age terms in the Vita s. Ecgwini are as follows:

pueritia: .i. .viii. annis [that is 8 years]

adolescentia: :xiiii. annis [14 years]

iuuentute: .l. annis constat [lasts until 5 o years]

senectute: innumeris annis constat [lasts innumerable years]

pueritia: .vii. annorum constat [lasts seven years]

adolescentia: .i. .xiiii. [that is 14 years]

senectute: .i. .l. Sicut sunt quattuor etates hominis, sic sunt quattuor uarietates mundi uel quattuor elementa (.i. ignis, aer, humor, aqua) uel tempora anni (.i. uer, estas, autumpnus, hiemps). [that is fifty. Like there are four ages of man, so there are four parts of the world and four elements

6o Byrhtferth, Vita s. Ecgwini 1.6., ed. and trans. Lapidge, 216-19. 
(that is fire, air, earth, water) and four seasons (that is spring, summer, fall and winter) $]^{61}$

The notion in these glosses that the four ages can be linked to the four parts of the world, the four elements and the four seasons is indeed similar to what Byrhtferth propagated in his computistical handbook. The age limits for the ages, however, do not correspond to those provided in his most extensive diagram De concordia mensium atque elementorum. While the number of years for adolescentia (14) may in fact refer to the duration of stage of life, rather than the age limit, the age limits provided for pueritia (7/8), iuuentus (50) and senectus (innumerable years) are clearly different from those in the diagram (14, 48 and $70 / 80$, respectively). It is possible that these numbers were adjusted in the transmission of the glosses or the diagram or that Byrhtferth, not unlike people such as Isidore of Seville, worked with differing age limits per stage of life.

At the end of the Vita s. Ecgwini, Byrhtferth attempts to place the four ages of man in an elaborate allegorical framework: Ecgwine is described as attacking each of the four Gates of the Devil's city in the four successive stages of his life; the four Gates are each manned by two evil leaders, whose wives represent eight deadly sins. ${ }^{62}$ As Lapidge has noted, the execution of this allegory is "idiosyncratic and inconsistent throughout." ${ }^{33}$ Ecgwine first defeats Pride and Vainglory at the Eastern gate in his adolescentia; Anger and Strife are defeated next at the Southern gate, in his pueritia; at the Western gate, "ab adolescentia" [after? adolescentia, i.e. iuuentus?], the wives named Sodom and Gomorrah are defeated; and, lastly, in presumably the last stage of his life, Ecgwine defeats Fornication and Filth. In Byrhtferth's allegory, the order of the ages as well as their links to the four wind directions are unlike those found in the Enchiridion and its associated diagrams, but its overall message is clear: the saint overcame sin throughout his life, from childhood to old age.

With the exception of Byrhtferth's confused tetradic allegory in the Vita s. Ecgwini, his treatment of the ages of man is marked by consistency throughout his works. The Latin terminology shows almost no variation, barring a single use of infantia as an equivalent for pueritia in his De concordia mensium atque elementorum. The qualities, seasons and elements that are linked to the four ages of man are consistently in line with the tradition represented by Bede. As will be demonstrated below, this consistency makes it unlikely that the

$61 \quad$ Byrhtferth, Lives, ed. and trans. Lapidge, 314. Translations mine.

62 Byrhtferth, Vita s. Ecgwini 4.1-4, ed. and trans. Lapidge, 269-77.

63 Byrhtferth, Lives, ed. and trans. Lapidge, 269 n. 5 . 
diagram of the four ages of woman in Gonville and Caius College, Ms 428/428 can be ascribed to Byrhtferth.

\section{The Diagram in Gonville and Caius College, MS 428/428}

The unique diagram in Gonville and Caius College, Ms 428/428 (see Fig. 1.3) indicates the correlation between individual stages of life, depicted as women, and the bodily humors and their associated qualities. The earliest stage, at the top of the diagram, features a depiction of pueritia, shown cross-legged and raising her hand, possibly dancing. The text in the diagram associates pueritia with the humor phlegm and the qualities "frigida et humida" [cold and moist]. The next stage, iuuentus, is depicted on the right side of the diagram, as a woman wearing a dress and holding up a stylized plant. Her associated humor is blood, along with the qualities "calida et humida" [warm and moist]. Mirroring iuuentus on the left side of the diagram is senectus, depicted as a woman with long braided hair, sitting on a chair and winding thread off her drop spindle onto a niddy noddy, or skein winder, to make skeins (balls of yarn). Her humor is identified as the warm and dry humor red choler or yellow bile. At the bottom of the diagram, decrepitas, depicted as a seated elderly woman, spins fiber into thread, using a distaff and drop spindle. Her associated humor is black choler or black bile, cold and dry. If the plant held by iuuentus is a flax plant, the last three images of the diagram show the process of spinning yarn in a chronological fashion: the harvesting of the flax plant; containing the unspun fiber on a distaff and spinning it into yarn with a drop spindle; and, lastly, making the yarn from the drop spindle into skeins, useful for measuring out, dying and storing the spun threads. ${ }^{64}$ The order of the spinning process is not matched by the order of the four life stages depicted: decrepitas (typically the last stage of the life course) spins the yarn, while senectus makes the yarn into skeins.

Before placing the diagram in Gonville and Caius College, MS 428/428 and the contents of its accompanying text within the context of early medieval English

64 I am grateful to Christina Petty for helping me identify the objects and activities depicted in this diagram. Sears, Ages of Man, 24-25, has suggested that the spinning process here may be related to the idea of the 'thread of life' and that the artist chose to use female figures to represent the ages because of the connection between the thread of life and the female Fates. However, the four female figures may also simply represent the grammatical gender of the names of the ages, as is the case with other humanoid figures in this manuscript. 


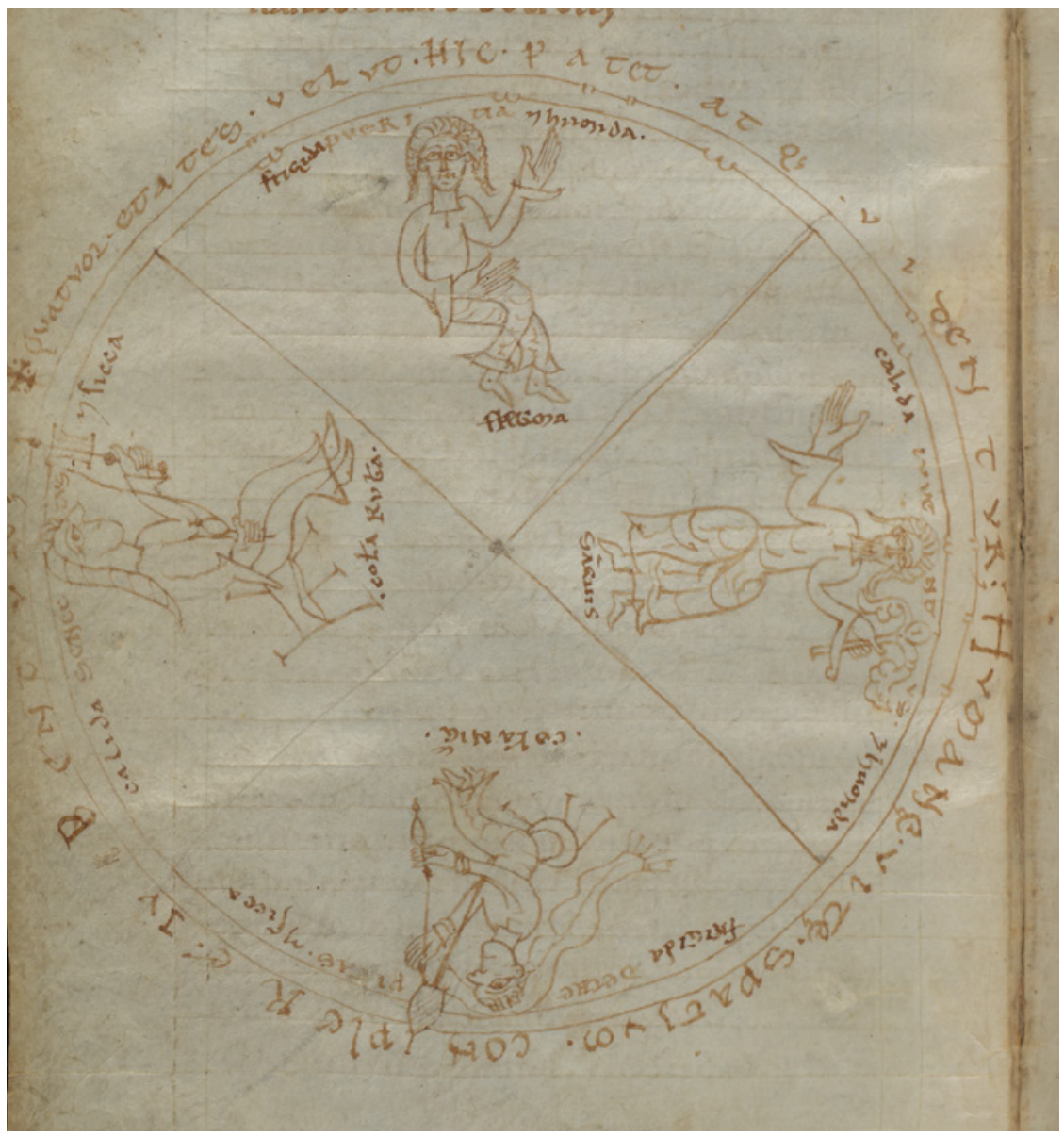

FIGURE 1.3 Diagram of the ages of woman in Cambridge, Gonville and Caius College, MS $428 / 428$, fol. $28 \mathrm{v}$

BY PERMISSION OF THE MASTER AND FELLOWS OF GONVILLE AND CAIUS COLLEGE, CAMBRIDGE

life course schematizations and those of Byrhtferth of Ramsey in particular, the manuscript context needs to be sketched.

The manuscript is in a single hand and contains only one text, the Tractatus de quaternario. This text is a handbook on tetradic cosmology, outlining the "quaternarii uim et potentiam" [the strength and power of the number four] as it recurs in the four wind directions, four seasons, four elements and various other tetrads. ${ }^{65}$ The text is divided into four booklets, each containing multiple chapters. Commenting on the manuscript's illumination, M. R. James has noted how " $[\mathrm{t}]$ he volume is full of large initials and diagrams, roughly

65 Gonville and Caius College, Ms 428/428, fol. 1 r. 
but effectively executed. The figure-drawing is very unskillful, not so the ornament." ${ }^{66}$ The diagrams are typically circular rotae divided into four parts, depicting humanoid representations of the four elements, the four humors, the four parts of the world, the four seasons, the four turning points of the sun, the four crescents of the moon and several other tetrads. The humanoid figures typically correspond to the grammatical gender of the nouns that they depict: in the rota depicting the four seasons, for instance, the feminine nouns hiemps 'winter' and estas 'summer' are depicted as women, while neuter ver 'spring' and masculine autumnus 'autumn' are male. ${ }^{67}$ Each of these sets of four is connected to the four qualities: hot and cold; dry and moist.

The manuscript's origins, whether English or continental, are unclear. The ornamented initials are in a continental, German style and the Pregothic round minuscule script, too, has a number of continental, German features. In particular, the form of the Tironian $e t$, the little flag at the end of the $e$ and the shapes of the nasal stroke and the narrow long $s$ suggest that the scribe was trained in Germany. ${ }^{68}$ The hand can be dated to around 115 o, on the basis of the presence of a number of 'kissing' and 'biting' letters. ${ }^{69}$ While the scribe may have been trained in Germany, this does not necessarily exclude the possibility of an English provenance for this manuscript, since many continental scribes worked in England after the Norman Conquest. ${ }^{70}$ A later annotation on fol. $36 \mathrm{v}$ shows that the manuscript must have been in England at least by the fourteenth century, since a fourteenth-century hand added the following, typically English motet:

Jhesu fili virginis

rex celestis angminis

vbi nil tristicie

nichil est molestie.

Set pax et concordia

et eterna gloria

ihesu pie

66 M. R. James, A Descriptive Catalogue of the Manuscripts in the Library of Gonville and Caius College (Cambridge, 1907-14), 500.

67 Gonville and Caius College, Ms 428/428, fol. 32v.

68 I am grateful to Erik Kwakkel who helped me localize and date the script.

69 Erik Kwakkel, "Kissing, Biting and the Treatment of Feet: The Transitional Script of the Long Twelfth Century," in Turning Over a New Leaf: Change and Development in the Medieval Book, ed. Erik Kwakkel, Rosamond McKitterick, and Rodney Thomson (Leiden, 2012), 78-126.

70 See, e.g., Erik Kwakkel, "Hidden in Plain Sight: Continental Scribes in Rochester Cathedral Priory, 1075-1150," in Writing in Context: Insular Manuscript Culture, 500-1200, ed. Erik Kwakkel (Leiden, 2013), 231-61. 
Jesus, son of the Virgin, king of the heavenly hosts where there is no sorrow nor affliction. But only peace and harmony and perpetual glory. $\mathrm{O}$ blessed Jesus. ${ }^{71}$

This addition suggests that the manuscript was likely in England two centuries after the text was written. Another potential indication that the manuscript was in fact made in England is that the book is dedicated to one "Hernalde frater dilectissime" [most beloved brother Hernaldus]. ${ }^{72}$ Hernaldus is a name that, in this spelling, occurs in English sources of the twelfth and thirteenth centuries, even though the name itself is typically assumed to be a continental German import. ${ }^{73}$ In sum, the manuscript seems to be the work of a scribe trained in Germany who was writing around 1150, possibly in an English monastery.

\section{5 The Tractatus de quaternario on the Ages of Man}

While the manuscript itself was definitely not produced by Byrhtferth of Ramsey, a number of eye-skips in the text suggest that the scribe may have been working from an earlier copy (or possibly a draft version of his own work). Further analysis of the contents of the text, therefore, is necessary in order to see how the diagram and its accompanying text relate to ideas about the human life course in early medieval England, particularly in the light of its possible attribution to Byrhtferth, whose texts and diagrams also survive in twelfth-century manuscripts.

The Tractatus author starts his discussion of the human life course by outlining a traditional fourfold division of the four ages and their accompanying complexions:

Est autem prima ętas adolescentia que secundum quorumdam opinionem calidę et humidę complexionis est. Et est ab ortu natiuitatis usque ad xxv vel xxx annum. Est et iuuentus calidæ et siccæ secundum eosdem

71 This motet is discussed by Renata Pieragostini, "Rediscovering Lost Evidence: Littleknown Fragments with English Polyphony in Bologna," Music \& Letters 92 (2011): 350-51, who does not mention the attestation in Gonville and Caius College, MS 428/428.

72 Gonville and Caius College, Ms 428/428, fols. 1r, $29 v$.

73 See Thorvald Fossner, Continental-Germanic Personal Names in England in Old and Middle English Times (Uppsala, 1916), 33-35. The spelling Hernaldus for the German name Arnold is found in various English documents, whereas the German spelling is typically Arnoldus, although Hernoldus is also found. See Adolf Socin, Mittelhochdeutsches Namenbuch: Nach oberrheinischen Quellen des 12. und 13.Jahrhunderts (Hildesheim, 1966), s.vv. 'Arnoldus', 'Hernoldus'. I am grateful to James Chetwood for sharing his views on this name in the context of twelfth-century England. 
complexionis ad xlv vel 1 annum perseuerans. Est et senectus frigida et sicca lv vel lx annum apperens a finibus suis. Huic succrescit senium frigidę et humidę complexionis. Quę etas sui temporis cursus termino uitę metitur. ${ }^{74}$

The first age is adolescentia which according to the opinion of some is of hot and moist complexion and this is from the onset of birth until 25 or 30 years. And, according to the same, iuuentus is of a hot and dry complexion, continuing until 45 or 50 years. And senectus is cold and dry, appearing at its end 55 or 6 o years. Senium, of a cold and moist complexion, succeeds them, which age of its course of time measures until the end of life.

The fourfold system here is similar to that found in Byrhtferth's work in connecting this same sequence of humoral qualities (from hot and moist to cold and moist) to four consecutive stages of life. However, it differs from Byrhtferth in the terminology used as well as in the age limits attributed to each stage. Indeed, the Tractatus author here, as both Sears and Cochelin have noted, follows a system found in the Isagoge ad Tegni Galieni by Johannitius (Hunayn Ibn Ishạaq), the ninth-century Arabic physician whose work was translated into Latin at the end of the eleventh century. ${ }^{75}$

In three following chapters, the Tractatus discusses "rurs alia secundum philosophus etatum discretio" [yet another division of ages, according to philosophers]. ${ }^{76}$ This turns out to be a sevenfold division of life, into infantia, pueritia, adolescentia, iuuentus, senectus, senium and decrepitas (see Table 1.5). The author explains that the "phisici" [physicians] divided the life course into four, in accordance with the four humors and the four qualities, while these philosophers based their seven ages on the seven planets. This correlation between the ages and the planets is ultimately derived from Ptolemy, whose works only became available in the mid-twelfth century, when they were translated from Arabic into Latin. ${ }^{77}$ Another crucial difference between the first fourfold scheme and this sevenfold scheme in the Tractatus is the sequence of qualities associated with the consecutive life stages. Whereas the scheme of the physicians shows a development from hot and moist (blood) to cold and moist (phlegm), the scheme of the philosophers has human life start out as cold and moist (phlegm) and end cold and dry (black bile).

74 Gonville and Caius College, MS 428/428, fols. 29v-3or.

75 Sears, Ages of Man, 163 n. 69. Cochelin, "Pre-Thirteenth-Century Definitions," 33, rightly notes that the Tractatus author pushes back old age by ten years, since Johannitius has iuuentus end at the age of 35 or 40 .

76 Gonville and Caius College, Ms 428/428, fol. 3or.

77 See Sears, Ages of Man, 52; Burrow, Ages of Man, 36 -38. 


\begin{tabular}{|c|c|c|c|c|c|c|c|}
\hline $\begin{array}{l}\text { Age term } \\
\text { (Age limit) }\end{array}$ & $\begin{array}{l}\text { infantia } \\
(7)\end{array}$ & $\begin{array}{l}\text { pueritia } \\
(14)\end{array}$ & $\begin{array}{l}\text { adolescentia } \\
(21)\end{array}$ & $\begin{array}{l}\text { iuuentus } \\
(35)\end{array}$ & $\begin{array}{l}\text { senectus } \\
(45)\end{array}$ & $\begin{array}{l}\text { senium } \\
(55)\end{array}$ & $\begin{array}{l}\text { decrepitas } \\
(7 \circ / 8 \circ)\end{array}$ \\
\hline $\begin{array}{l}\text { Planet } \\
\text { Qualities }\end{array}$ & $\begin{array}{l}\text { Moon } \\
\text { cold } \\
\text { and } \\
\text { moist }\end{array}$ & $\begin{array}{l}\text { Mercury } \\
\text { dry, partly } \\
\text { cold, partly } \\
\text { moist, } \\
\text { partly hot }\end{array}$ & $\begin{array}{l}\text { Venus } \\
\text { hotter and } \\
\text { less moist }\end{array}$ & $\begin{array}{l}\text { Sun } \\
\text { hot and } \\
\text { dry }\end{array}$ & $\begin{array}{l}\text { Mars } \\
\text { less hot, } \\
\text { drier } \\
\text { than the } \\
\text { sun }\end{array}$ & $\begin{array}{l}\text { Jupiter } \\
\text { partly hot, } \\
\text { partly } \\
\text { cold, dry }\end{array}$ & $\begin{array}{l}\text { Saturn } \\
\text { colder and } \\
\text { drier }\end{array}$ \\
\hline
\end{tabular}

Subsequently, the Tractatus author tries to synthesize both schemes and produces a scheme which is deemed "ueritate assistere" [to attend to the truth]. Naturally, the fourfold scheme of the physicians is preferred, but the Tractatus links this to the arrangement of humoral qualities proposed by the philosophers. The author also proposes yet another set of age limits, unlike the other two sets enumerated earlier:

TABLE 1.6 The Tractatus author's preferred scheme (Tractatus de quaternario $3 \cdot 5^{-} 7$ )

\begin{tabular}{lllll}
\hline $\begin{array}{l}\text { Age } \\
\text { (Age limit) }\end{array}$ & $\begin{array}{l}\text { pueritia/adolescentia } \\
(14)\end{array}$ & $\begin{array}{l}\text { iuuentus } \\
\left(45 / 5^{\circ}\right)\end{array}$ & $\begin{array}{l}\text { senectus } \\
(6 \circ / 65)\end{array}$ & $\begin{array}{l}\text { senium } \\
(-)\end{array}$ \\
\hline $\begin{array}{l}\text { Humor } \\
\text { Qualities }\end{array}$ & $\begin{array}{l}\text { phlegm } \\
\text { cold and moist }\end{array}$ & $\begin{array}{l}\text { blood } \\
\text { hot and moist }\end{array}$ & $\begin{array}{l}\text { red bile } \\
\text { hot and dry }\end{array}$ & $\begin{array}{l}\text { black bile } \\
\text { cold and dry }\end{array}$
\end{tabular}

The author then proposes, without providing a rationale, to change the names of the four ages into the traditional terms pueritia, adolescentia, iuuentus and senectus. ${ }^{78}$ Notably, these terms are still different from the ones used in the diagram of the ages of woman (pueritia, iuuentus, senectus and decrepitas), which does, however, show the same distribution of qualities (from cold and moist to cold and dry). In the remainder of the text on this subject, the Tractatus author defends at length the correlation between the ages and their proposed qualities, albeit without any further explication of the terminology used or the age limits provided. For instance, the author notes how children might seem hot because of their constant movement but those physicians who ascribe the

78 As Sears, Ages of Man, 24 has noted, this set of terms is similar to that used by Byrhtferth of Ramsey, which may have led some to connect the scheme to Byrhtferth. 
quality hot to children mistake this heat for natural heat. In fact, the author claims, children are actually cold and moist and people gradually lose moisture throughout their lives. This loss of moisture is caused by switching from watered-down food to more solid foods later in life and because of the "emissionem pubertatis puerilis [...] libidinis [...] etiam successiui seminis" [the discharging of youthful puberty, lust and also of superfluous seed] ${ }^{79}$ Hence, the last stage of life is 'dry and cold', just like the wood that fueled a fire ends up as cold, dried-out charcoal. As such, the Tractatus author dismisses the physicians' claim that the ultimate stage of life, senectus or senium, is marked by the quality moist. This moistness, according to the Tractatus author, is "non naturalis sed accidentalis" [not natural but accidental]; it is caused by the degeneration of nerves, muscles and fat, not the kind of life-giving moisture that stands at the beginning of life: "pueri sua humiditate excrescant, senes incurvantur" [children grow through their moistness, old people become curved]. ${ }^{80}$ Since natural moisture that is consumed in the first two stages of life does not return naturally, the last stage of life must be marked by natural dryness.

From the above reading, it becomes clear that this text, like the manuscript itself, cannot be attributed to Byrhtferth of Ramsey. Instead, we are dealing with an unnamed author who is responding to new ideas about the human life course that entered Western European medical discourse between the end of the eleventh century and the middle of the twelfth century. In fact, the text appears to be one of the first of its kind to explicitly problematize the existence of varying ideas of the human life course and, in particular, the different opinions concerning the relation of the individual stages to the humoral qualities. The fourfold division that the Tractatus author eventually defends, moving from a cold and moist pueritia to a cold and dry senectus, is completely unlike the schemes propagated by Bede and Byrhtferth, which move from a hot and moist pueritia to a cold and moist senectus.

Whether writing homilies, encyclopedic works or prayers, early medieval English authors stuck to a flexible but uniform definition of the human life course into three main stages, pueritia, iuuentus and senectus. These stages could each be subdivided, resulting into divisions of life into four, five or six 'ages of man', which could be used interchangeably. Threefold and sixfold schemes typically followed patristic traditions of biblical exegesis, while the fourfold pattern had its basis in natural philosophy. The latter scheme features

79 Gonville and Caius College, MS 428/428, fol. 31v.

8o Gonville and Caius College, Ms 428/428, fol. $3^{2 r}$. 
most prominently in various works attributed to Byrhtferth of Ramsey, ranging from his computistical handbook with diagrams to his hagiography and glosses.

The discussion found in the mid-twelfth-century Tractatus de quaternario represents a departure from the uniform system of life course stratification found in pre-Conquest texts. Specifically, the Tractatus author seeks to synthesize traditional connections between the four ages and the four humors, as found in works by Bede and Byrhtferth, with ideas about the human life course that had newly been introduced in Western Europe by the twelfth century. Incorporating insights from a sevenfold division of life, the Tractatus author comes to a new fourfold scheme with a completely different sequence of humoral qualities than that found in earlier works. The suggestion that Byrhtferth of Ramsey may have been responsible for the Tractatus and its diagram of the four ages of woman must be rejected on account of the Tractatus's explicit dismissal of the fourfold life course definition that resounds so consistently throughout Byrhtferth's literary output. Byrhtferth may have written a lot during his lifetime, but the Tractatus de quaternario should not be included in his ever-expanding oeuvre. 